Table Profile of patients

\begin{tabular}{|c|c|c|c|c|c|}
\hline No & Age & Signs E symptoms & Histology & $S T D s$ & $C I N$ \\
\hline $\begin{array}{l}1 \\
2\end{array}$ & $\begin{array}{l}39 \\
21\end{array}$ & $\begin{array}{l}\text { Warts, Pruritus, Hyperpigmented pinkish patch } \\
\text { Warts, discomfort, pruritus }\end{array}$ & VIN II/III & none & $\begin{array}{l}\text { neg } \\
\text { I-1988( } 2 \text { y prev) }\end{array}$ \\
\hline & & Raised mauve patch & VIN II & none & $\mathrm{I}-1989$ (1 y prev) \\
\hline 3 & 33 & Single wart/pruritus & VIN III & none & CIN I \\
\hline $\begin{array}{l}4 \\
5\end{array}$ & $\begin{array}{l}57 \\
38\end{array}$ & $\begin{array}{l}\text { Perianal wart, periclitorial brown patch, pruritus } \\
\text { Irritation } 4 \text { y Exacerbation } 1 \text { y Pink brown lesion, }\end{array}$ & VIN III & none & neg \\
\hline & & pruritus & VIN III & none & neg \\
\hline $\begin{array}{l}6 \\
7\end{array}$ & $\begin{array}{l}27 \\
25\end{array}$ & $\begin{array}{l}\text { Pigmented warty area } \\
\text { Warts }\end{array}$ & $\begin{array}{l}\text { VIN II/III } \\
\text { VIN I }\end{array}$ & $\begin{array}{l}\text { none } \\
\text { none }\end{array}$ & $\begin{array}{l}\text { II/III } \\
\text { neg }\end{array}$ \\
\hline 8 & 23 & $\begin{array}{l}\text { White patches } 2 \text { y } \\
\text { Pruritus } 6 \text { months }\end{array}$ & VIN II/III & $\begin{array}{l}\text { History of } \\
\text { gonorrhoea }\end{array}$ & \\
\hline 9 & 19 & $\begin{array}{l}\text { Brownish lesions, } \\
\text { pruritus }\end{array}$ & VIN III & none & $\begin{array}{l}\text { Wart Virus } \\
\text { Change }\end{array}$ \\
\hline 10 & 26 & $\begin{array}{l}\text { Warts, discomfort, } \\
\text { pigmented areas }\end{array}$ & $\begin{array}{l}\text { Acanthosis } \\
\& \text { keratosis }\end{array}$ & none & $\begin{array}{l}\text { Focal inflammation } \\
\text { No CIN }\end{array}$ \\
\hline 11 & 17 & $\begin{array}{l}\text { Blackish spots, } \\
\text { irritation }\end{array}$ & $\begin{array}{l}\text { Seborrhoeic } \\
\text { keratosis }\end{array}$ & none & CIN 1 \\
\hline
\end{tabular}

cytology was normal, except in cases 2 and 3, where dysplasia was reported.

Though VIN has been thought of as a rare phenomenon up to about 15 years ago, more recent reports indicate a higher prevalence and at a younger age-as does our small series of nine patients in 11 months. Most reports indicate a close association with $\mathrm{HSV}$ and other STD. ${ }^{3}$ We are unable to substantiate this, as none of our patients had associated STDs except warts. An association between $\mathrm{CIN}$ and VIN has been known and this was confirmed in four of our nine patients who had CIN too, even though Pap smears were negative. The clinical appearance of VIN is all important and cannot be overstated. Campion aptly reports that it is the most "productive diagnostic technique". ${ }^{2}$ Lesions are papular or macular, single or multiple, and over $60 \%$ are hyperkeratotic. In our series, contrary to published reports, ${ }^{4} 67 \%$ were solitary: pruritus in seven $(78 \%)$ of the nine was the main presenting feature. None of our patients were immunocompromised $^{5}$ though this is a known at-risk group.

Detection of VIN with Toludene blue is not reliable with false negative/positive results being common. Colposcopy is a better diagnostic tool.

In a series of 10 patients with co-existing proven CIN, biopsy of suspicious warts failed to substantiate the correlation that is said to exist between $\mathrm{CIN}$ and VIN. ${ }^{2}$ We suspect that the same process that leads to CIN also leads to VIN but in the more resistant vulval skin, it takes longer to manifest. The hypothesis that VIN is more likely to follow CIN is now under investigation, following the chance finding of CIN in our VIN patients.

If this hypothesis were true, then any patient with VIN must also have/had CIN but this is not always the case. In our patient group, $50 \%$ were reported to have CIN compared with $20 \%$ reported to date. ${ }^{2}$ We believe VIN is of multifactorial aetiology, some of which have yet to be identified. The possible presence of CIN should be investigated in the presence of VIN.

Though the malignant potential of VIN is uncertain, the intraepithelial changes may persist for long periods to accelerate rapidly at a later stage. The associated risk of neoplasia of other sites in the genital tract in general, and cervix in particular, should trigger the clinician to be vigilant at all times.

A H DE SILVA
S SIVAPALAN
V HARINDRA
R BASU ROY
Department of Genito-Urinary Medicine,
Royal Bournemouth Hospital,
Castle Lane East,
Bournemouth BH7 $7 D W, U K$

Address correspondence to: Dr R Basu Roy.

1 Graham A Barker. Progress in Obstetrics and Gynaecology 1990;25:389.

2 Campion MJ, Singer A. Vulval intraepithelial neoplasia: clinical review: Genitourin Med 1987;63:147-52.

3 Kaufman RH, Dreesman GD, Burek J. Herpes virus induced antigens in squamous cell carcinoma in situ of induced antigens in squamous cell carcin
the vulva. $N$ Engl $₹$ Med 1981;305:483.

4 Townsend DE, Levine RU, Richart RM, Crum CM, Petrilli ES. Management of vulvar intra epithelial neoplasia. Obstet Gynaecol 1982;60:49.

5 Woodruff JD, Hildebrandt EE. Obstet Gynaecol 1958; 12:414.

Accepted for publication 6 July 1992

\section{Prodromal symptoms in genital herpes simplex infection}

Many individuals with genital herpes simplex virus (HSV) infection report that they are able to predict at least a proportion of attacks through warning prodromal sensations. However the frequency and reliability of such sensations is not known.

The consistent use of condoms during intercourse will reduce the risk of transmission of HSV. However, the use of condoms is not always possible either because a couple desire a pregnancy or one or other partner is unwilling to use condoms. Under these circumstances warning sensations may be of value in reducing the risk of transmission if, in an individual, they reliably predict the onset of an attack and that individual makes appropriate changes in their sexual behaviour.

Ninety subjects suffering from recurrent genital herpes simplex virus infection (HSV), aged 19-60 years (mean, 34 years), 40 men and 50 women, were recruited from members of the Herpes Association $(n=60)$ and from a genitourinary medicine clinic $(n=30)$. The Herpes Association patients were sent a postal questionnaire (return rate $=60 \%$ ). GUM clinic patients were approached while in the clinic (participation rate $100 \%$ ). Subjects were asked about the frequency with which they experienced two different premonitory symp- 
Table Number of subjects reporting two prodromal symptoms by frequency of occurrence

\begin{tabular}{llllll}
\hline & $0 \%$ & $25 \%$ & $50 \%$ & $75 \%$ & $100 \%$ \\
\hline Genitals & $7(18 \cdot 9 \%)$ & $13(14 \cdot 4 \%)$ & $7(7 \cdot 8 \%)$ & $15(16 \cdot 7 \%)$ & $38(42 \cdot 2 \%)$ \\
Legs & $62(68 \cdot 9 \%)$ & $9(10 \cdot 0 \%)$ & $7(7 \cdot 8 \%)$ & $4(4 \cdot 4 \%)$ & $7(7 \cdot 8 \%)$ \\
Overall & $15(16 \cdot 7 \%)$ & $11(12 \cdot 2 \%)$ & $8(8 \cdot 9 \%)$ & $16(17 \cdot 8 \%)$ & $39(43 \cdot 3 \%)$ \\
\hline
\end{tabular}

toms in the day preceding an attack, sensations around the area of the genitals preceding attacks, or sensations in the backs of the legs. They were also asked whether they changed their sexual behaviour in response to the sensations.

The table shows the number of subjects reporting each of the two prodromal symptoms by frequency of occurrence. The row marked "overall" shows the percentage of occasions on which they got either prodromal symptom and therefore is an index of their overall ability to predict an attack. It can be seen that 53 subjects $(59 \%)$ could reliably predict the onset of an attack on at least $75 \%$ of occasions by the presence of a warning sensation around the genitals. Only 17 subjects $(18.9 \%)$ did not have this premonitory symptom or could not predict an attack from it. However, a warning sensation down the back of the leg was less reliable. Only 11 subjects $(12 \cdot 2 \%)$ could use this sensation as a reliable indicator of an imminent attack. Overall 39 subjects (44\%) reported that they could always predict an attack.

In total, 67 subjects $(74 \%)$ reported that they responded to prodromal sensations by avoiding intercourse in the period after the sensations started. Clearly patients themselves use warning symptoms as a way of reducing the risk of transmission. Since $34 \%$ of subjects reported that intercourse provoked an attack they may also have served a purpose in avoiding a perceived provoking factor. Where warning sensations are present reliably before attacks the risk of transmission during the early stages of an attack may be reduced by the patient paying particular attention to such sensations. However, such sensations are unlikely to prevent transmission through asymptomatic shedding. Patient use of warn- ing sensations may however, in part, be responsible for the relatively low overall rate of transmission reported between partners ${ }^{1}$ and the relative importance of infection from asymptomatic shedding reported from some studies. ${ }^{2}$ The value of such warning symptoms may be less during the first three months after the first attack where asymptomatic shedding is reported to be greater. ${ }^{3}$ The value of such warning sensations may also be reduced while patients are on continuous oral acyclovir, where asymptomatic shedding may occur even where the attacks themselves are suppressed. ${ }^{4}$

Encouraging patients to attend to warning sensations may be of value in reducing the risk of transmission somewhat where other means of risk-reduction are unavailable or unacceptable. The value to the patient will depend on the reliability of such sensations. Studies of the transmission of HSV also need to take into account possible changes in sexual behaviour occurring as a result of spontaneous patient monitoring of such warning sensations.

JOHN L BROOKES SERENA HAYWOOD St Mary's Hospital Medical School, London W2 $1 N Y$ JOHN GREEN Department of Behavioural Sciences, St Mary's Hospital Medical School, London W2 INY, UK

Address correspondence to: $\mathrm{Dr} J$ Green

1 Mertz GJ, Benedetti J, Ashley R, Selke SA, Corey L. Risk factors for the sexual transmission of genital herpes. $A n n$ factors for the sexual transmiss
Intern Med 1992;116:197-202.

2 Mertz GJ, Coombs RW, Ashley R, et al. Transmission of genital herpes in couples with one symptomatic and one asymptomatic partner: a prospective study. $\mathcal{F}$ Infect Dis 1988:157:1169-77.

3 Koelle DM, Benedetti J, Langenberg A, Corey L. Asymptomatic reactivation of herpes simplex virus in women after the first episode of genital herpes. Ann Intern Med 1992:116:433-7.

4 Bowman CA, Woolley PD, Herman S, Clarke J, Kinghorn GR. Asymptomatic herpes simplex virus shedding from the genital tract whilst on suppressive doses of oral the genital tract whilst on suppressive
acyclovir. Int $\Im$ STD AIDS 1990:1:174-7. 